\title{
STUDI KOMPARASI AKHLAK \\ SISWA BOARDING SCHOOL DAN NON BOARDING SCHOOL DI SMA AL-MA'SOEM SUMEDANG
}

\author{
Kardiyah,* \\ Munawar Rahmat, Udin Supriadi, \\ Program Studi Ilmu Pendidikan Agama Islam \\ Fakultas Pendidikan Ilmu Pengetahuan Sosial, Universitas Pendidikan Indonesia \\ *E-mail :kardiyah@student.upi.edu
}

\begin{abstract}
ABSTRAK
Penelitian ini dilatarbelakangi oleh problematika Akhlak siswa yang semakin krusial, serbuan arus liberalisme yang tidak terbendung seolah mempengaruhi 'style' di kalangan remaja, sikap hedonis menjadi gaya hidup yang seringkali menabrak ramburambu dalam beragama dan bernegara, di sisi lain sekolah-sekolah yang berbasis Islām terus menjamur. Penelitian ini bertujuan untuk menganalisis perbedaan Akhlak siswa boarding school dan non boarding school di SMA Al-Ma'soem. Metode yang digunakan dalam penelitian ini yaitu metode deskriptif dengan pendekatan kuantitatif jenis rancangan komparatif dua variabel bebas, dengan desain penelitian survei berupa angket. Data diambil dengan teknik penarikan sampel berkelompok satu tahap (cluster random sampling), adapun teknik pengolahan data menggunakan analisis data deskriptif dan analisis data inferensial dengan bantuan Microsoft Excel dan Sofware SPSS 20. Berdasarkan semua dimensi Akhlak yang dijadikan penelitian, yaitu Akhlak terhadap diri sendiri, Akhlak terhadap orang tua dan keluarga, dan Akhlak terhadap sesama manusia dan masyarakat, maka hasil penelitian setelah dibandingkan dari ketiga dimensi tersebut, diketahui bahwa Akhlak siswa boarding school dan siswa non boarding school dengan menggunakan rumus Chi kuadarat diperoleh nilai sebesar 0,107. Jika dilihat pada chi kuadrat tabel taraf signifikansi 5\% yaitu sebesar 5,991, maka nilai chi kuadrat pada penelitian ini lebih kecil yaitu 0,107< 5,991. Dari hasil tersebut diketahui bahwa tidak terdapat perbedaan secara signifikan Akhlak siswa boarding school dan siswa non boarding school.
\end{abstract}

Kata Kunci: Komparasi; Akhlak; Boarding; non Boarding. 


\section{PENDAHULUAN}

Dewasa ini Problematika Akhlak dikalangan remaja semakin krusial. Bangsa yang dahulu dikenal akan tutur kata yang indah, sikap yang bijak, kepudilian yang meninggi saat ini sedikit demi sedikit bergeser menjadi bangsa yang arogan dan kejam.Tindak kriminalitas yang terus meningkat seperti kasus kekerasan, pembunuhan, perkosaan, pencurian dan tindak kriminalitas lainnya.Sepanjang 2014 Komisi Nasional Perlindungan Anak menerima 2737 aduan kasus dan yang menjadi sorotan adalah tawuran antar pelajar tawuran" (Bagja, 2014).

Fenomena kenakalan remaja seperti bola salju yang terus menggeliding dan akhirnya membesar sehingga nampak terlihat dengan jelas, satu demi satu berita kriminalitas terus bermunculan di media masa. Hal tersebut, sebenarnya memiliki dua sisi yang jika salah 'melihat' maka akan salah juga dalam menyikapi, karena ada beberapa kasus yang diberitakan oleh media justru menjadi 'inspirasi' bagi orang lain untuk bertindak hal yang sama.

Hasil penelitian Yayasan Kita dan Buah Hati bersama Rafa Health dan Beauty Lifestyle (RHBL) sejak Januari 2008 hingga Ferbuari 2010 tentang prilaku anak terhadap pornografi. Penelitian ini berdasarkan 2818 sampel yang diambil pada kelas 4-6 Sekolah Dasar. Hasilnya sungguh mengejutkan, sebanyak $67 \%$ anak ternyata pernah melihat dan mengakses pornografi. Bahkan, 37\% diantarnya mengakses dari rumah (Chatib 2012, hal. 189).

Executive Director of The Foundationkita dan Buah Hati Elly Risman Musa (dalam Chatib, 2012, hlm. 189) memperingatkan dengan tegas bahwa "Indonesia berada di 'jurang kehancuran' menghadapi dahsyatnya ancaman bencana adiktif pornografi yang menyerang pelajar sebagai generasi muda Indonesia". "Pada bulan september telah terjadi tindakan perkosaan di Bandung yang dilakukan oleh anak-anak sekolah dasar terhadap balita yang masih berusia empat tahun" (Nasrul, 2014). Berita ini adalah warningbagi para orang tua,agar lebih hati-hati dalam mendidik dan mengawasi anak.

Pejabat tinggi negara yang seharusnya memberikan figur contoh yang baik untuk anak bangsa, anggota dewan yang menjadi representatif rakyat seringkali melukai hati rakyat dengan prilakunya yang seringkali mengabaikan etika, perilaku koruptif seolah menjadi budaya di negeri ini dari pejabat tingkat bawah sampai kalangan elit yang terjerat kasus korupsi.

Kementrian Dalam Negeri pada pertengahan 2014 sebagaimana Jawapos memberitakan bahwa "327 kepada daerah yang terbelit korupsi, angka ini setara $86 \%$ dari total 524 kepada daerah yang dipilih secara langsung" (Kurniawan, 2014). Hal yang sering dilakukan oleh kaum terdidik adalah kekerasan, tidak amanah, tindak korupsi, daya juang rendah, rendah disiplin kerja, mudah puas, mementingkan diri sendiri, integritas kurang, melemahnya sikap bernegara, dan berbagai bentuk split persolality lainnya yang sering membuat gundah lingkungan dimana mereka berada (Elfindri dkk. 2012, hlm. 5).

Pendidikan seharusnya mampu menjadi solusi atas segala permasalahan yang terjadi di bangsa ini, khusunya problematika Akhlak.Tujuan pendidikan dalam Islam adalah untuk melahirkan manusia yang baik. Tujuan tersebut begitu indah dimana output dari proses pendidikan seharusnya melahirkan manusia-manusia yang beradab.Namun, realitas yang terjadi justru banyak kaum terdidik yang tidak beradab(Al-Attas, 2010, hlm. 191). 
Al-Attas (2010, hlm. 191) menambahkan bahwa Konsep pendidikan Islam adalah penanaman $a d a b$, kerena $a d a b$ dalam pengertian yang luas meliputi kehidupan spiritual dan material manusia yang menumbuhkan sifat kebaikan yang dicarinya. Maka dari itu, melalui lembaga-lembaga pendidikan Islam yang terus menjamur seharusnya mampu menjadi benteng terakhir dari segala hal yang mampu merusak moralitas anakanak negeri.

Melihat fenomena yang terjadi di bangsa ini, maka permasalahan yang paling fundamental khususnya dikalangan pelajar yaitu problematika Akhlak yang semakin krusial. Penting kiranya semua elemen masyarakat bersatu untuk menyelesaikan 'Ujian Nasional' yang sedang menguji bangsa ini, terutama bagi lembaga pendidikan yang berbasis Islam seharusnya mampu menjadi pilar-pilar perbaikan atas problematika Akhlak yang sedang terjadi.

Pesantren merupakan salah satu pilar lembaga pendidikan di Indonesia yang telah teruji dalam membentuk konsep diri dan membangun karakter setiap orang agar menjadi pribadi yang tangguh, handal, dan berakhlak mulia. Seiring dengan perkembanagn zaman, serta tuntutan masyarakat atas kebutuhan, saat ini banyak pesantren yang terus berinovasi sehingga tidak dipungkiri bahwa semakin menjamurnya lembaga-lembaga pendidikan berbasis Islamic boarding school di tengahtengah masyarakat.

Yayasan Pendidikan Al-Ma'soem salah satu lembaga pendidikan yang dinilai sangat lengkap karena memiliki jenjang pendidikan dari tingkat dasar sampai perguruan tinggi. Al-Ma'seom sendiri berani 'tampil beda' dengan konsep boarding dan non boarding yang terintegrasi di masing-masing jenjangnya. Oleh karena latar belakang tersebut,peneliti tertarik untuk meneliti perbandingan Akhlak siswa boarding school dan siswa non boardingdan mengkaji seberapa pengaruh keberadaan siswa dilingkungan pesantren terhadap Akhlak yang ditampilkan seharihari.maka itu, peneliti mengambil sebuah judul:"Studi Komparasi Akhlak Siswa Boarding School dan non Boarding School di SMA Al-Ma'soem".

Ibn Miskawih menyatakan bahwa Akhlak adalah sifat yang tertanam dalam jiwa yang mendorongnya untuk melakukan perbuatan tanpa memerlukan pemikiran dan pertimbangan. Senada dengan itu Imam Al-Ghazali menyatakan bahwa Akhlak adalah sifat yang tertanam dalam jiwa yang menimbulkan macam-macam perbuatan dengan gampang dan mudah, tanpa memerlukan pemikiran dan pertimbangan(dalam Nata, 2003, hal. 34).

Nurdin dkk. (2001, hal. 205-209) memiliki pandangan bahwa ruang lingkup Akhlak mencakup hal-hal sebagai berikut:

a. Pola hubungan manusia dengan Allāh SWT.

b. Pola hubungan manusia dengan Rasūlullah SAW.

c. Pola hubungan manusia dengan dirinya sendiri.

d. Pola hubungan dengan keluarga.

e. Pola hubungan dengan masyarakat.

Rahmat (2012, hal. 37) menyatakan bahwa faktor-faktor yang memperkuat Akhlak, adalah:

1. Terbimbing oleh seorang guru yang Shaleh.

2. Kokohnya iman.

3. Memiliki pengetahuan agama yang cukup dan benar.

4. Memilki falsafah hidup yang baik

5. Memiliki lingkungan pergaulan yang baik.

6. Sisioner (memiliki wawasan ke depan)

7. Terpenuhi kebututan pokok. Rahmat (2012, hal. 47-54) menyatakan ada enam faktor yang 
memperlemah akhlak yaitu: (a) hidup mewah, (b) miskin harta, (c) lingkungan pergaulan yang buruk, (d) menganggur, (e) minim pengetahuan agama atau memiliki banyak pengetahuan agama tapi tidak tahu mana yang inti dan mana yang cabang, dan (f) negative thingking.

Berbeda halnya dengan pendapat sebelumnya, Zahruddin (2004, hal. 93) menyatakan bahwa ada empat faktor mempengaruhi baik-buruknya Akhlak yaitu (a) Insting (Naluri), (b) Adat, (c) Wirotsah (keturunan) dan (d) Milieu (segala apa yang melingkupi manusia dalam arti yang luas seperti udara, tanah dan yang lainnya).

Rizkiani (2012, hlm. 13) menyatakan bahwa boarding school merupakan kata dalam bahasa inggris yang terdiri dari dua kata yaitu boarding dan school, boarding berarti menumpang dan school berarti sekolah, kemudian diserap dalam bahasa indonesia menjadi sekolah berasrama.

Sejalan dengan itu, Dimyati (2015) menyatakan bahwa istilah lain dari boarding school adalah sekolah berasrama dimana siswa mengikuti pendidikan reguler dari pagi hingga siang di sekolah kemudian dilanjutkan dengan pendidikan agama atau pendidikan nilai-nilai khusus di malam hari, selama 24 jam siswa berada di bawah pendidikan dan pengawasan para guru pembimbing.

Munculnyasekolah berasrama (boarding school) yaitu sejak pertengahan tahun 1990 di Indonesia. Hal ini dilatarbelakangi oleh kondisi pendidikan Indonesia yang selama ini berlangsung dipandang belum memenuhi harapan yang ideal. Boarding school yang pola pendidikannya lebih komprehensif-holistik lebih memungkinkan untuk menciptakan lingkungan pendidikan yang ideal dan melahirkan orang-orang yang akan dapat membawa gerbong dan motor pergerakan kehidupan sosial, politik, ekonomi dan agama Khamdiyah ( dalam Sutris, 2009, hlm 3)

Tedapat beberapa jenis boarding school, namun tidak semua jenis boarding school terdapat di Indonesia. Berikut jenis boarding school menurut Rizkiana (dalam Yahya, 2009):

a. Sekolah berdasarkan Agama, contohnya adalah Pesantren

b. Sekolah dengan pelajar berjenis kelamin sama contohnya St Margaret's School for Girls Victoria.

c. Sekolah militer, di Indonesia contohnya SMU Taruna Nusantara.

d. Sekolah Pra-Profesional seni, melatih pelajar menjadi seniman di berbagai bidang sepeti musik, akting, teater, ballet, dan penulis.

e. Sekolah berkebutuhan khusus seperti para remaja bermasalah, autis

f. Sekolah junior yang menyediakan Boarding School di bawah tahap SMA

Ada beberapa keunggulan boarding school yaitu: program pendidikan paripurna, lingkungan yang kondusif, siswa yang heterogen, dan jaminan keamanan (Dimyati, 2015). Adapun penjelasan komponenkomponen tersebut adalah sebagai berikut:
a. Program pendidikan paripurna
b. Lingkungan yang kondusif
c. Siswa yang heterogen
d. Jaminan keamanan

Ada beberapakekurangan dalam sistem boarding school hal tersebut terjadi karena beberapa faktor, Dimyati (2015) mengungkapan ada tiga faktor yaitu: dikotomi guru sekolah dengan guru asrama, kurikulum pengasuhan yang tidak baku, sekolah dan asrama terletak dalam satu lokasi. Adapun penjelasan faktor-faktor tersebut adalah sebagai berikut:

a. Dikotomi guru sekolah dan guru asrama

b. Kurikulum Pengasuhan yang tidak baku 
c. Sekolah dan Asrama terletak dalam satu lokasi

\section{METODE PENELITIAN}

Penelitian ini merupakan peneltian kuantitatif dengan jenis rancangan komparatif dua variabel bebas dengan desain penelitian survei. Desain dalam penelitian ini yaitu menggunakan rancangan perbandingan kelompok. Mertler (2011, hlm. 155) menyatakan bahwa gagasan umum di balik rancangan perbandingan kelompok adalah bahwa dua kelompok atau lebih yang dihadapkan pada kondisiyang berbeda, diperbandingkan berdasarkan pengukuran yang umum dan tunggal untuk melihat apakah kondisi yang berbeda tersebut bisa menimbulkan hasil yang juga berbeda.

Mengingat banyaknya jumlah populasi siswa di SMA Al-Ma'soem, maka tidak semua populasi menjadi sasaran dalam pengumpulan data. Adapun penetapan sampel yang diambil dari populasi yaitu menggunakan teknik penarikan sampel berkelompok satu tahap (cluster random sampling) sehingga diperoleh sampel dalam penelitin ini berjumlah 11 kelas yaitu $X$ MIA 1, X MIA 7, X IIS 1, XI MIA 1, XI MIA 6, XI Aksel, XI IIS 1, XII MIA 1, XI MIA 5, XII Aksel, dan XII IIS 1. Maka diperoleh jumlah sampel sebanyak 284 orang yang terdiri dari 130 siswa boarding (tinggal di asrama), sementara 154 siswa non boarding.

Instrumen yang digunakan dalam peneltian ini berupa angket yang terdiri dari 40 item yang mencakup 17 indikator dan 3 dimensi, yaitu: Pertama, Akhlak terhadap diri sendiri, kedua Akhlak terhadap orang tua dan keluarga, dan ketiga Akhlak terhadap sesama manusia dan masyarakat. Adapun angket yang tersebut berisi pernyataanpernyataan dengan menggunkan skala likert tiga tingkatan. Pernyataan yang disajikan pada instrumen tersebut ada dua pertama pernyataan yang bernilai positip, kedua pernyataan yang bernilai negatif. Jika jawaban dari pertanyaan yang bermuatan positif (+) maka penskorannya yaitu 3,2 , dan 1 sementara untuk skor jawaban dari pertanyaan yang bermuatan negatif (-) sebaliknya yaitu 1, 2, dan 3 .

Analisis data dalam penelitian ini dilakukan dengan uji statistik menggunakan rumus Chi Kuadrat, yaitu untuk mengetahui perbedaan Akhlak siswa boarding school dengan Akhlak siswa non boarding school. Adapun teknik yang digunakan dalam penelitian ini, yaitu analisis data deskriptif dan analisis data statistik inferensial yang dibantu dengan bantuan program Microsoft Excel dan Sofware SPSS.

\section{HASIL DAN PEMBAHASAN}

Penelitian ini dilakukan untuk mengetahui perbedaan antara Akhlak siswa boarding school dan Akhlak siswa non boarding school di SMA AlMa'seom, dalam hal ini peneliti melakukan penilaian pada dimensi Akhlak terhadap diri sendiri, Akhlak terhadap orang tua dan keluarga, dan Akhlak terhadap sesama manusia dan masyarakat.

Diagram 1

\section{Profil Kualitas Akhlak Siswa Boarding} SchoolTerhadap diri sendiri

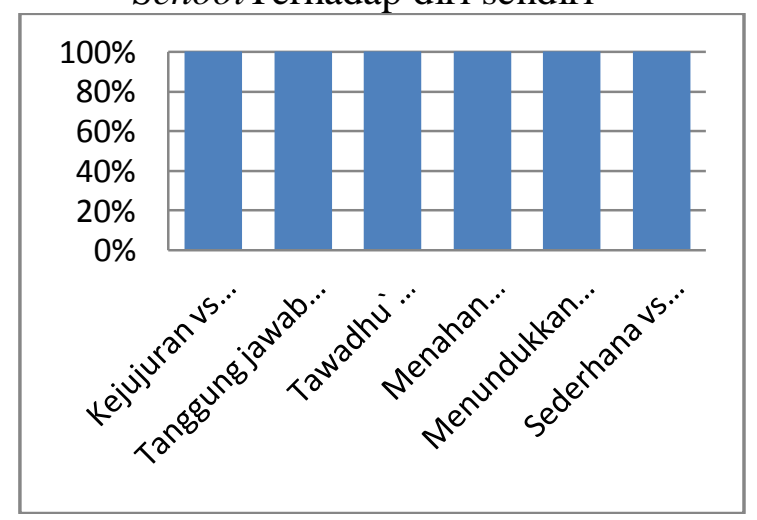

Pada diagram di atas memperlihatkan Akhlak siswa boarding schoolpada dimensi Akhlak terhadap diri sendiri mempunyai 6 indikator, yaitu: 
jujur vs dusta, khianat dan ingkar janji memperoleh hasil 279 atau $16 \%$ masuk dalam kategori sedang, tanggung jawab memperoleh hasil 304,5 atau $18 \%$ masuk kategori tinggi, rendah hati vs sombong memperoleh hasil 294 atau $17 \%$ masuk kategori sedang, menahan amarah vs dendam memperoleh hasil 253 atau $15 \%$ masuk dalam kategori sedang, menundukan pandangan memperoleh hasil 281 atau $17 \%$ masuk dalam kategori sedang, dan sederhana vs boros memperoleh hasil 294,5 atau 17\% masuk kategori sedang. Jika dilihat dari diagram di atas, maka terdapat 2 indikator yang memperoleh kategori tinggi yaitu tanggung jawab dan menahan amarah dan dendam.

\section{Diagram 1}

Profil kualitas AkhlakSiswa Boarding SchoolTerhadap Orang Tua dan Keluarga

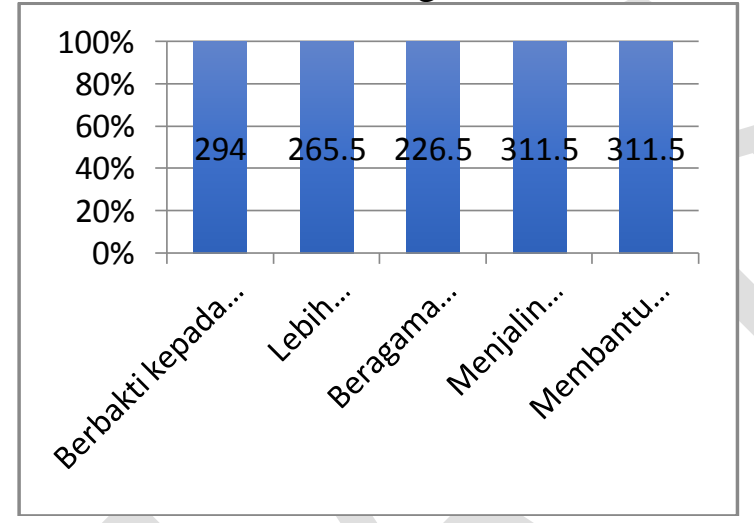

Pada diagram di atas memperlihatkan Akhlak siswa boarding schoolpada dimensi Akhlak terhadap orang tua dan keluarga mempunyai 5 indikator yaitu: berbakti kepada ibubapak memperoleh hasil 294 atau 21\% masuk kategori sedang, lebih mendahulukan bakti kepada ibu memperoleh hasil 265,5 atau $19 \%$ masuk kategori sedang, beragama mengikuti Rasul walau beda dengan ibu bapak memperoleh hasil 226,5 atau $16 \%$ masuk kategori sedang, menjalin silaturahim dengan keluarga memperoleh hasil 311,5 atau $22 \%$ masuk kategori tinggi, membantu keluarga memperoleh hasil 311,5 atau $22 \%$ masuk kategori tinggi. Pada dimensi Akhlak terhadap orang tua dan keluaraga, ada 2 indikator yang memperoleh kategori tinggi yaitu menjalin silaturahim dengan keluarga, dan membantu keluarga.

\section{Diagram 3}

Profil Kualitas Akhlak Siswa Boarding Schoolterhadap Sesama Manusia dan Masyarakat

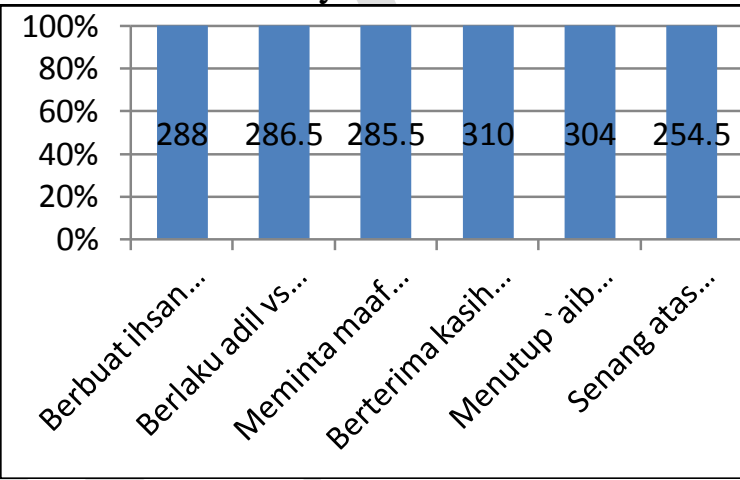

Pada diagram di atas memperlihatkan Akhlak siswa boarding schoolpada dimensi Akhlak tehadap sesama manusia dan masyarakat memiliki 6 indikator yaitu, berbuat iḥsān memperoleh hasil 288 atau 17\% masuk dalam kategori sedang, berlaku adil vs berbuat zālim memperoleh hasil 286,5 atau $16 \%$ masuk dalam kategori sedang, meminta maaf dan memaafkan memperoleh hasil 285,5 atau $16 \%$ masuk kategori sedang, berterima kasih atas kebaikan orang memperoleh hasil 310 atau $18 \%$ masuk kategori tinggi, menutup aib memperoleh hasil 304 atau 18\% masuk kategori tinggi, dan sangat senang atas keberhasilan orang vs iri memperoleh hasil 254,5 atau $15 \%$ masuk dalam kategori sedang. Pada dimensi Akhlak terhadap sesama manusa dan masyarakat, ada 2 indikator yang memperoleh kategori tinggi yaitu berterima kasih atas kebaikan orang dan menutup aib. 
Diagram 4

Profil Kualitas Akhlak Siswa Boarding

School perdimensi

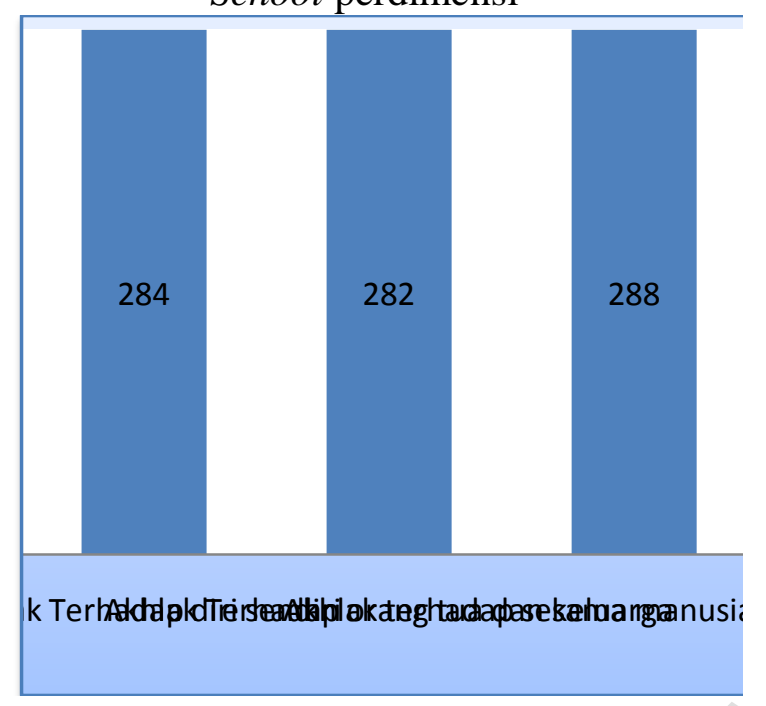

Dari hasil diagram di atas menunjukan bahwa dimensi Akhlak terhadap diri sendiri memperoleh nilai sebesar 284, Akhlak terhadap orang tua dan keluarga memperoleh nilai sebesar 282, dan Akhlak terhadap sesama manusia dan masyarakat memperoleh hasil 288, dan dimensi Akhlak terhadap sesama manusia dan masyarakat dilihat dari bentuk diagramnya terlihat paling unggul atau tinggi dibandingkan dengan bentuk diagaram dimensi yang lainnya. Namun, jika dalam kategorisasi nilai masing-masing dimensi yaitu, Akhlak terhadap diri sendiri masuk dalam kategori sedang, Akhlak terhadap orang tua dan keluarga masuk kategori sedang, dan Akhlak terhadap sesama manusia dan masyarakat masuk dalam ketegori sedang.
Diagram 5

Profil kualitas Akhlak siswa non boardingterhadap diri sendiri

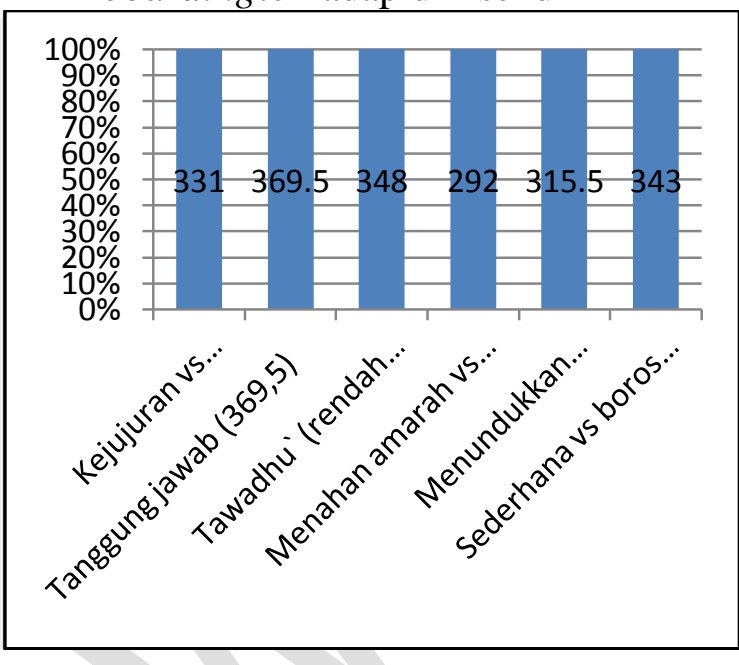

Pada diagram di atas memperlihatkan Akhlak siswanon boarding schoolpada dimensi Akhlak terhadap diri sendiri yaitu mempunyai 6 indikator yaitu: prilaku jujur vs dusta, khianat dan ingkar janji memperoleh hasil 331 atau $17 \%$ masuk dalam kategori sedang, tanggung jawab memperoleh hasil 369,5 atau $18 \%$ masuk kategori tinggi, rendah hati vs sombong memperoleh hasil 348 atau $17 \%$ masuk kategori sedang, menahan amarah vs dendam memperoleh hasil 392 atau 15\% masuk dalam kategori tinggi, menundukan pandangan memperoleh hasil 315,5 atau $16 \%$ masuk dalam kategori sedang, dan sederhana vs boros memperoleh hasil 343 atau $17 \%$ masuk kategori sedang. Jika dilihat dari diagram di atas, maka hanya terdapat 1 indikator yang memperoleh kategori tinggi yaitu tanggung jawab. 
Diagram 6

Prosentase AkhlakTerhadap orang tua dan keluarga

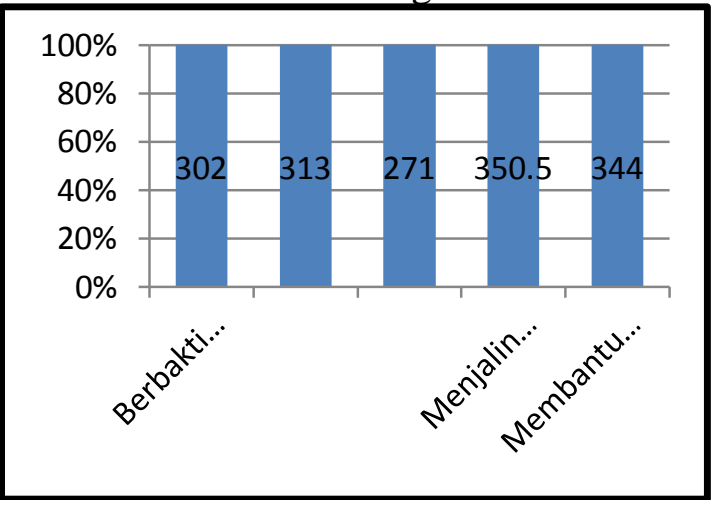

Diagram di atas memperlihatkan Akhlak siswa boarding schoolpada dimensi Akhlak terhadap orang tua dan keluarga mempunyai 5 indikator yaitu berbakti kepada ibu-bapak memperoleh hasil 302 atau 19\% masuk kategori rendah, lebih mendahulukan bakti kepada ibu memperoleh hasil 313 atau $20 \%$ masuk kategori sedang, beragama mengikuti Rasul walaupun beda dengan ibu bapak memperoleh hasil 271 atau $17 \%$ masuk kategori sedang, menjalin silaturahim dengan keluarga memperoleh hasil 350,5 atau $22 \%$ masuk kategori sedang, membantu keluarga memperoleh hasil 344 atau $23 \%$ masuk kategori sedang. Pada dimensi Akhlak terhadap orang tua dan keluagra tidak ada indikator yang masuk dalam kategori tinggi.

\section{Diagram 7}

Profil kualitas Akhlaksiswa non boarding School terhadap sesama manusia dan masyarakat

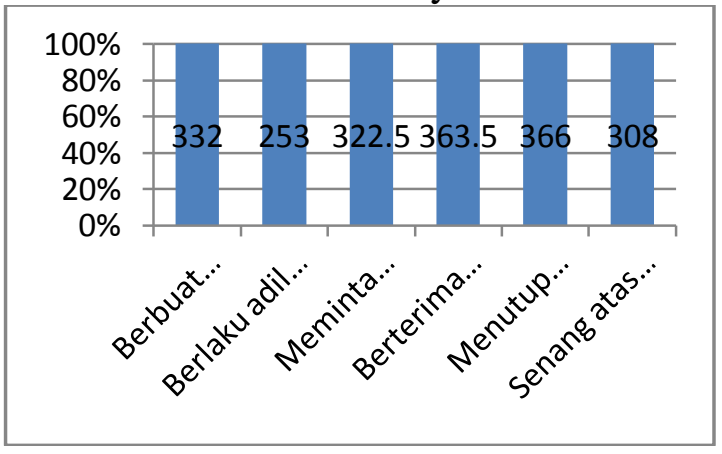

Diagram di atas memperlihatkan Akhlak siswa boarding schoolpada Dimensi Akhlak tehadap sesama manusia dan masyarakat memiliki 6 indikator yaitu, berbuat ị̣sān memperoleh hasil 332 atau $17 \%$ masuk dalam kategori sedang, berlaku adil vs berbuat zālim memperoleh hasil 253 atau $13 \%$ masuk dalam kategori sedang, meminta maaf dan memaafkan memperoleh hasil 322,5 atau $16 \%$ masuk kategori sedang, berterima kasih atas kebaikan orang memperoleh hasil 363 atau $19 \%$ masuk kategori tinggi, menutup aib memperoleh hasil 366 atau $19 \%$ masuk kategori tinggi, dan sangat senang atas keberhasilan orang vs iri memperoleh hasil 308 atau 16\% masuk dalam kategori sedang. Pada dimensi Akhlak terhadap sesama manusa dan masyarakat, ada 2 indikator yang memperoleh kategori tinggi yaitu berterima kasih atas kebaikan orang dan menutup aib.

\section{Diagram 8}

Profil kualitas Akhlak Siswa non boarding schoolperdimensi

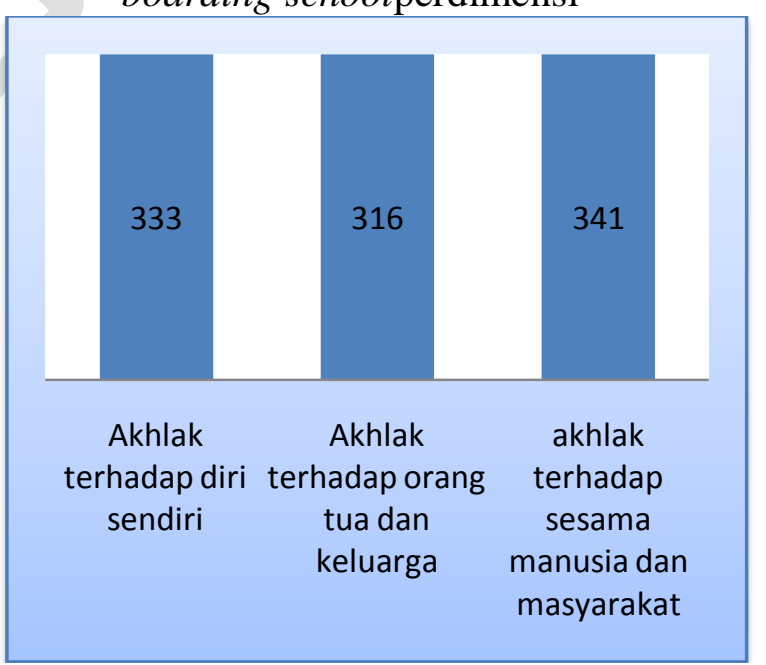

Dari hasil diagram di atas menunjukan bahwa dimensi Akhlak terhadap diri sendiri memperoleh nilai sebesar 333, Akhlak terhadap orang tua dan keluarga memperoleh nilai sebesar 316, dan Akhlak terhadap sesama manusia dan masyarakat memperoleh hasil 341, dan dimensi Akhlak terhadap sesama 
manusia dan masyarakat dilihat dari bentuk diagramnya terlihat paling unggul atau tinggi dibandingkan dengan bentuk diagaram dimensi yang lainnya. Namun, jika dalam kategorisasi nilai masing-masing dimensi yaitu, Akhlak terhadap diri sendiri masuk dalam kategori sedang, Akhlak terhadap orang tua dan keluarga masuk kategori sedang, dan Akhlak terhadap sesama manusia dan masyarakat masuk dalam ketegori sedang.

Tabel 1

Perbandingan Akhlak siswa boarding school dan siswa non boarding school

\begin{tabular}{|c|c|c|c|c|}
\hline & & \multicolumn{2}{|c|}{ Akhlak Total } & \multirow[t]{2}{*}{ Total } \\
\hline & & Sedang & Tinggi & \\
\hline \multirow{8}{*}{$\begin{array}{l}\text { Siswa } \\
\text { Boarding } \\
\text { Siswa } \\
\text { Non } \\
\text { Boarding }\end{array}$} & Count & 107 & 23 & 130 \\
\hline & Expected & 108,0 & 22,0 & 130,0 \\
\hline & & & & \\
\hline & Count & 129 & 25 & 154 \\
\hline & Expected & 1280 & 260 & 1540 \\
\hline & Count & & 20,0 & 154,0 \\
\hline & Count & 236 & 48 & 284 \\
\hline & $\begin{array}{l}\text { Expected } \\
\text { Count }\end{array}$ & 236,0 & 48,0 & 284,0 \\
\hline & & & $\mathrm{Va}$ & ue \\
\hline Pearson & i-Square & & &, $107^{\mathrm{a}}$ \\
\hline
\end{tabular}

Berdasarkan nilai chi kuadarat pada tabel di atas diperoleh nilai sebesar 0,107 . Jika dibandingkan dengan chisqure tabel pada taraf signifikansi 5\% dan $\mathrm{dk}=(3-1) \times(2-1)=2$ adalah sebesar 5,991 maka nilai chi-suere pada penelitian lebih kecil yaitu $0,107<5,991$. Ini menunjukan bahwa tidak terdapat perbedaan Akhlak secara menyeluruh antara siswa boarding school dan siswa non boarding school.

Profil kualitas Akhlak siswa boarding school pada dimensi Akhlak terhadap diri sendiri hanya ada 1 indikator yang memiliki kualiatas Akhlak yang tinggi yaitu tanggung jawab dengan skor angket 304,5. sementara indikator jujur vs dusta, khianat dan ingkar janji, rendah hati vs sombong, menahan amarah vs dendam, menundukan pandangan dan sederhana vs boros memiliki kualitas Akhlak yang sedang karena skor angket yang diperoleh tidak lebih kecil dari 237 dan tidak lebih besar dari 303 .

Profil kualitas Akhlak siswa non boarding school dalam dimensi Akhlak kepada diri sendiri juga sama hanya ada 1 indikator yang memiliki kualitas Akhlak yang tinggi yaitu tanggung jawab dengan skor angket sebesar 369,5, sementara indikator jujur, vs dusta, khianat dan ingkar janji, rendah hati vs sombong, menundukan pandangan dan sederhana vs boros memiliki kualitas yang sedang karena skor angket yang diperoleh tidak lebih kecil dari 257 dan tidak lebih besar dari 359. Untuk lebih jelas perbedaan antara siswa boarding school dan non boarding school perindikator seperti yang digambarkan berikut ini:

a) Jujur vs dusta, khianat dan ingkar janji, siswa boarding school memperoleh hasil 279 atau $16 \%$ masuk kategori sedang sementara siswa non boarding school memperoleh hasil 331 atau $17 \%$ masuk kategori sedang.

b) Tanggung jawab, siswa boarding school memperoleh hasil 304,5 atau $18 \%$ masuk kategori tinggi sementara siswa non boarding school memperoleh hasil 369.5 atau $18 \%$ masuk kategori tinggi.

c) Tawā school memperoleh hasil 294 atau $17 \%$ masuk kategori sedang sementara siswa non boarding school memperoleh hasil 348 atau $17 \%$ masuk kategori sedang.

d) Menahan amarah vs marah dan dendam, siswa boarding school memperoleh hasil 253 atau $15 \%$ masuk kategori sedang sementara siswa non boarding 
schoolmemperoleh hasil 292 atau $15 \%$. masuk kategori sedang.

e) Menundukan pandangan, siswa boarding school memperoleh hasil 281 atau $17 \%$ masuk kategori sedang sementara siswa non boarding school memperoleh hasil 315,5 atau $16 \%$ masuk kategori sedang.

f) Sederhana vs boros siswa boarding school memperoleh hasil 294,5 atau $17 \%$ masuk kategori sedang sementara siswa non boarding school memperoleh hasil 343 atau $17 \%$ masuk kategori sedang.

Jika dirata-ratakan dimensi Akhlak terhadap diri sendiri pada siswa boarding school yang berjumlah 130 memperoleh hasil 284 dengan kategori sedang, dalam perolehan hasil tersebut dapat disimpulkan bahwa Akhlak siswa boarding school terhadap diri sendiri tidak konsisten atau tidak istiqamah karena jawaban yang siswa isi dalam angket Akhlak terhadap diri sendiri didominsi jawaban kadang-kedang.

Begitu juga dengan siswa non boarding school yang berjumlah 154 memperoleh hasil 333 dengan kategori sedang, dalam perolehan hasil tersebut dapat disimpulkan bahwa siswa non boarding school terhadap diri sendiri tidak konsisten atau tidak istiqamah karena jawaban yang responden isi dalam angket Akhlak terhadap diri sendiri didominasi jawaban kadangkadang.

Profil kualitas Akhlak siswa boarding school pada dimensi Akhlak terhadap orang tua dan keluarga, terdapat 2 indikator yang memiliki kualiatas Akhlak yang tinggi yaitu indikator menjalin silaturahim dengan keluarga dengan skor 311,5 dan membantu keluarga dengan skor 311,5, sementara indikator berbakti kepada ibubapak, lebih mendahulukan bakti kepada ibu, beragama mengikiti rasul walaupun berbeda dengan ibu bapak yaitu memiliki kualitas Akhlak yang sedangkarena skor angket tidak lebih kecil dari 237 dan tidak lebih besar dari 303.

Adapun profil kualitas Akhlak siswa non boarding school dalam dimensi Akhlak kepada orang tua dan keluarga tidak ada satu indikator yang memiliki kualitas Akhlak yang tinggi, mulai indikator dari berbakti kepada ibubapak, lebih mendahulukan bakti kepada ibu, beragama mengikuti rasul walaupun berbeda dengan ibu-bapak, menjalin silaturahim dengan keluarga dan membantu keluarga memiliki kualitas yang sedang karena skor angket tidak lebih kecil dari 257 dan tidak lebih besar dari 359.Untuk lebih jelas perbedaan anatar siswa boarding school dan non boarding school perindikator seperti yang digambarkan berikut ini:

a. Berbakti kepada ibu bapak siswa boarding school memperoleh hasil 294 atau $21 \%$ masuk kategori sedang, sementara siswa non boarding school memperoleh hasil 302 atau 19\% masuk kategori sedang.

b. Lebih mendahulukan bakti kepada ibu siswa boarding school memperoleh hasil 265,5 atau 19\% masuk kategori sedang sementara siswa non boarding school memperoleh hasil 313 atau $20 \%$ masuk kategori sedang.

c. Beragama mengikuti rasul (walau berbeda dengan ibu-bapak) siswa boarding school memperoleh hasil 226,5 atau $16 \%$ masuk kategori sedang sementara siswa non boarding school memperoleh hasil 271 atau 17\% masuk kategori sedang.

d. Menjalin silaturahim dengan keluraga siswa boarding school memperoleh hasil 311,5 atau $22 \%$ masuk kategori tinggi sementara siswa non boarding school memperoleh hasil 350,5 atau $22 \%$ masuk kategori sedang.

e. Membantu keluarga siswa boarding school memperoleh hasil 311,5 atau $22 \%$ masuk kategori tinggi, sementara siswa non bording school 
memperoleh hasil 344 atau 22\% masuk kategori sedang.

Jika dirata-ratakan dimensi Akhlak terhadap orang tua dan keluara pada siswa boarding school yang berjumlah 130 memperoleh hasil 282 dengan kategori sedang, dalam perolehan hasil tersebut dapat disimpulkan bahwa Akhlak siswa boarding school terhadap diri sendiri tidak konsisten atau tidak istiqamah karena jawaban yang siswa isi dalam angket Akhlak terhadap diri sendiri didominsi jawaban kadangkadang.

Begitu juga dengan siswa non boarding school yang berjumlah 154 memperoleh hasil 316 dengan kategori sedang, dalam perolehan hasil tersebut dapat disimpulkan bahwa siswa non boarding school terhadap diri sendiri tidak konsisten atau tidak istiqamah karena jawaban yang siswa isi dalam angket Akhlak terhadap diri sendiri didominasi jawaban kadang-kadang.

Profill kualitas Akhlak siswa boarding school pada dimensi Akhlak terhadap sesama manusia dan masyarakat terdapat 2 indikator yang memiliki kualiatas Akhlak yang tinggi yaitu dalam indikator berterima kasih atas kebaikan orang dengan skor angket 310, dan menutup aib dengan skor 304, sementara indikator berlaku adil vs berbuat zālim, meminta maaf dan memaafkan dan senang atas keberhasilan kawan vs iri memiliki kualitas Akhlak yang sedangkarena skor angket tidak lebih kecil dari 237 dan tidak lebih besar dari 303 .

Adapun profil kualitas Akhlak siswa non boarding school dalam dimensi Akhlak terhadap sesama manusia dan masyarakat terdapat 2 indikator yang memiliki kualiatas Akhlak yang tinggi yaitu berterima kasih atas kebaikan orang dengan skor angket 363,5 dan menutup aib dengan skor angket 366, dan ada 1 indikator yang memiliki kualitas rendah yaitu indikator berlaku adil dan berbuat zāāim dengan skor 253, sementara indikator meminta maaf dan memaafkan dan senang atas keberhasilan kawan vs iri memiliki kualitas Akhlak yang sedangkarena skor angket tidak lebih kecil dari 257 dan tidak lebih besar dari 359.Untuk lebih jelas perbedaan anatar siswa boarding school dan non boarding school perindikator seperti yang digambarkan berikut ini:

a. Berbuat ihsān siswa boarding school memperoleh hasil 288 atau $17 \%$ masuk kategori sedang, sementara siswa non boarding school memperoleh hasil 332 atau $17 \%$ masuk kategori sedang.

b. Berlaku adil vs berbuat zālim siswa boarding school memperoleh hasil 286,5 atau $16 \%$ masuk kategori sedang sementara siswa non boarding school memperoleh hasil 253 atau $13 \%$ masuk kategori sedang.

c. Meminta maaf dan memaafkan siswa boarding memperoleh hasil 310 atau $18 \%$ masuk kategori tinggi sementara siswa non boarding memperoleh hasil 322,5 atau $16 \%$ masuk kategori sedang.

d. Berterima atas kebaikan orang siswa boarding school memperoleh hasil 310 atau $18 \%$ masuk kategori tinggi sementara siswa non boarding school memperoleh hasil 365,5 atau $19 \%$ masuk kategori tinggi.

e. Menutup aib siswa boarding school memperoleh hasil 304 atau 18\% masuk kategori tinggi sementara siswa non boarding school memperoleh hasil 366 atau $19 \%$ masuk kategori tinggi.

f. Senang atas keberhasilan kawan vs iri siswa boarding school memperoleh hasil 254,5 atau $15 \%$ sementara siswa non boarding school memperoleh 308 atau $16 \%$ masuk kategori sedang.

Jika dirata-ratakan dimensi Akhlak terhadap orang tua dan keluara pada siswa boarding school yang berjumlah 130 memperoleh hasil 288 dengan kategori sedang, dalam perolehan hasil tersebut dapat disimpulkan bahwa Akhlak siswa boarding school terhadap 
diri sendiri tidak konsisten atau tidak istiqamah karena jawaban yang siswa isi dalam angket Akhlak terhadap diri sendiri didominsi jawaban kadangkadang.

Begitu juga dengan siswa non boarding school yang berjumlah 154 memperoleh hasil 341 dengan kategori sedang, dalam perolehan hasil tersebut dapat disimpulkan bahwa siswa non boarding school terhadap diri sendiri tidak konsisten atau tidak istiqamah karena jawaban yang siswa isi dalam angket Akhlak terhadap diri sendiri didominasi jawaban kadang-kadang.

\section{KESIMPULAN}

Kualitas Akhlāq siswa boarding school SMA Al-Ma'soem umumnya berada pada kualifikasi Akhlāq sedang (82\%) atau sebanyak 107 siswa, sebagian kecil berada pada kualifikasi Akhlāq tinggi (18\%) atau sebanyak 23 siswa, dan tidak ada satupun siswa boarding school yang memiliki kualifikasi Akhlāq rendah. Adapun kualifikasi Akhlāq perdimensi adalah: (a). Akhlāq siswa boarding school terhadap diri sendiri sebanyak 22 siswa atau $(17 \%)$ berada pada kualifikasi Akhlāq tinggi, sedangkan 108 siswa atau $(83 \%)$ berada pada kualifikasi Akhlāq sedang dan tidak ada satupun siswa boarding school yang berada pada kualifikasi Akhlāq rendah. (b). Akhlāq siswa boarding school terhadap orang tua dan keluarga sebanyak 30 siswa atau (23\%), berada pada kualifikasi Akhlāq tinggi, sedangkan 99 siswa atau $(76 \%)$ berada pada kualifikasi Akhlāq sedang dan hanya ada 1 orang siswa boarding school yang berada pada kualifikasi Akhlāq rendah. (c). Akhlāq siswa boarding school terhadap masyarakat dan sesama manusia sebanyak 25 siswa atau $(19,2 \%)$ berada pada kualifikasi Akhlāq tinggi, sedangkan 105 siswa atau (80,8\%) berada pada kualifikasi Akhlāq sedang, dan tidak ada satupun siswa boarding school yang berada pada kualifikasi Akhlāq rendah.

Kualitas Akhlāq siswa non boarding school SMA Al-Ma'soem umumnya berada pada kualitas Akhlāq sedang $(79,9 \%)$ atau sebanyak 123 siswa, sebagian kecil berada pada kualifikasi Akhlāq tinggi (16\%) atau sebanyak 24 siswa, dan tidak ada satupun siswa non boarding school yang memiliki kualifikasi Akhlāq rendah. Adapun kualifikasi Akhlāq perdimensi adalah: (a). Akhlāq siswa non boarding school terhadap dirinya sendiri berada pada kualifikasi Akhlāq tinggi sebanyak 22 siswa atau $(14,3 \%)$, sedangkan 132 siswa atau $85,7 \%$ berada pada kualifikasi Akhlāq sedang dan tidak ada satupun siswa yang berada pada kualifikasi Akhlāq rendah. (b). Akhlāq siswa non boarding school terhadap orang tua dan keluarga berada pada kualifikasi Akhlāq tinggi sebanyak 23 siswa atau (14,9\%), sedangkan 126 siswa atau $(81,8 \%)$ berada pada kualifikasi Akhlāq sedang dan ada 5 siswa atau $(3,3 \%)$ berada pada kualifikasi Akhlāq rendah. (c). Akhlāq siswa non boarding school terhadap sesama manusia berada pada kualifikasi Akhlāq tinggi sebanyak 25 siswa atau $(16,2 \%)$, sedangkan 105 siswa atau $(83,8 \%)$ berada pada kualifikasi Akhlāq sedang, dan tidak ada satupun siswa yang berada pada kualifikasi Akhlāq rendah.

Dimensi Akhlāq yang dijadikan penelitian yaitu Akhlāq terhadap diri sendiri, Akhlāq terhadap orang tua dan keluarga, dan Akhlāq terhadap sesama manusia dan masyarakat, berdasarkan dari ketiga dimensi tersebut, peneliti membandingkan kualitas Akhlāq siswa boarding school dan siswa non boarding school dengan menggunakan rumus chi kuadrat menghasilkan bahwa tidak terdapat perbedaan Akhlāq secara signifikan Akhlāq siswa boarding school dan siswa non boarding school. 


\section{REFERENSI}

Alatas, M. N. (2010). Islam dan Sekulerisme. Bandung: Pimpim.

Bagja, K. (2014, Desember Selasa). Retrieved Januari Sabtu, 2015, fromhttp://metro.sindonews.com/rea d/943991/31/2-737-aduan-tawuranpaling-disoroti-sepanjang-20141419924767.

Chatib, M. (2012). Orangtuanya Manusia. Bandung: Mizan Pustaka.

Dimyati, D. (2015, Maret Jum'at). http://almasoem.sch.id.

Retrieved

MeiSabtu,2015,fromhttp://almas oem.sch.id/pesantren/problemdan-solusi-pendidikan-sekolah berasrama-boarding-school/

Elfindri. dkk. (2012). Pendidikan Karakter. Jakarta: Baduose Media Jakarta.

Khamdiyah. (2013). Sistem Boarding School dalam pendidikan Karakter Siswa Kelas VII Nurul Ummah Kota Gede Yogyakarta.(Skripsi, pada Fakultas Ilmu Tarbiyah UIN Sunan Kalijaga: tidak diterbitkan Kurniawan, A (2014, Desember Rabu). Retrieved Desember Minggu, 2014,fromhttp://www.jawapos.co $\mathrm{m} /$ baca/opinidetail/9907/WajahBuram-Kepala-Daerah
Mertler, C. A. (2011). Action Research (3 ed.). (Daryanto, Trans.) Yogyakarta: Pustaka Pelajar.

Nasrul, E. (2014, September Selasa). Retrieved Desember Minggu, 2014,from.http://nasional.republ ika.co.id/berita/nasional/hukum/1 4/09/16/nbzrhm-ya-ampunbalita-diperkosa-oleh-anak-sd.

Nata, A. (2005). Akhlak Tasawuf. Jakarta: Raja Grafindo Persada.

Nurdin, M. (2011). Moral dan Kognisi Islam. Bandung: Alfabeta.

Rahmat, M. (2012). Filsafat Akhlak . Bandung: Value Press.

Rizkiani, A. (2012). Pengaruh Sistem Boarding School terhadap Pembentukan Karakter Peserta Didik. Jurnal Pendidikan Universitas Garut, 13.

Zahruddin. (2004). Pengantar Studi Akhlak. Jakarta: Raja Grafindo Persada. 